\title{
Are We so Obsessed with Technology that We Fail to Apply Basic Logic to What We See? Has the Accumulation of Data Excluded Consideration of the Quality of the Data?
}

\section{Graham Ewing}

Mimex Montague Healthcare Limited, Nottingham, UK

"Corresponding author: Graham Ewing, Mimex Montague Healthcare Limited, Nottingham, UK, Tel: 0115-9890304; E-mail: graham.ewing@mmhcl.co.uk Rec Date: Feb 13, 2014; Acc Date: Feb 28, 2014; Pub Date: March 3, 2014

Copyright: (c) 2015 Ewing G. This is an open-access article distributed under the terms of the Creative Commons Attribution License, which permits unrestricted use, distribution, and reproduction in any medium, provided the original author and source are credited.

\section{Commentary}

We use genetic screening to establish the genes which are responsible for the production of specific proteins. When this technique was developed it was heralded as the ultimate solution: 'the answer to life, the universe and all that'; but as time has gone on we have come to recognise that it is extremely rare to be able to link one particular gene to the production of one particular protein because the expression of proteins involves the influence of many genes. The issue becomes all the more complicated now that it has been established that genetic/epigenetic changes occur with the onset of diabetes and obesity but that such changes can largely be reversed through a healthy lifestyle which incorporates a balanced diet and adequate levels of exercise $[1,2]$. How else can we explain that people can recover their health? Furthermore genetic changes are the inevitable consequence of the ageing process so rather than genetic changes being the cause of pathologies, at least in the case of lifestyle-related morbidities, genetic changes are often the consequence of pathological processes.

The genes are just part of the mechanism by which the brain is able to regulate the body's function. The collective function of genes have one role: to express proteins. If the levels of the expressed proteins declines then so too does the body's functional capacity.

The expression of a protein and its level are considered by medical research to be representative of the body's function however this line of logic is akin to measuring the flow of fuel to an internal combustion engine as a way of measuring its power/capacity. This ignores the flow of air and the engine timing. The logic is flawed yet it is upon such flawed logic that most biochemical marker-type tests are based. Is it surprising therefore that such tests are not especially accurate [3]? What is necessary is to take into account the prevailing reaction conditions and characterise each biochemical reaction in terms of its reaction kinetics [4-6] e.g. if the prevailing levels of intercellular acidity are altered it is inevitable that this must influence protein conformation (whether the proteins are coiled and reactive), the levels of essential minerals, the activity of enzymes and hence the rate at which proteins react with their reactive substrates.

The body's biochemistry provides us with a method to measure the rate of reaction: because most proteins and enzymes emit light which influences our colour perception [7-10]. So we have a convenient mechanism which is able to precisely determine the rate at which each biological and pathological reaction proceeds.

The latest fad is that of big data. Please forgive me for my scepticism. To derive meaningful results from the analysis of big data requires that the computer is fed data which can yield meaningful conclusions but it has never been possible in the history of mankind, to extract meaningful data from a random store of data, derived from experiential methods, which does not, and cannot therefore, fit the model. As illustrated earlier the store of 'big data' has significant limitations.

Is this the end of the story? Heavens no. What is the relationship between genotype and phenotype $[5,8]$ ? Perhaps the best illustration of the dilemma for medical research is in the area of diabetes where there is the genetic condition, type 1 , and the phenotypic condition, type 2 . The dilemma is that insulin is often prescribed for the treatment of type 2 diabetics yet it is the approved treatment for type 1 diabetes. Ergo type 1 and type 2 are comorbidities! Both must be considered when characterizing a biological and/or pathological reaction. Finally, where is the consideration of the neural mechanism which regulates the body's function [11-17].

\section{References}

1. Barrès R, Yan J, Egan B, Treebak JT, Rasmussen M, et al. (2012) Acute exercise remodels promoter methylation in human skeletal muscle. below Cell Metab 15: 405-411.

2. Booth FW, Chakravarthy MV, Spangenburg EE (2002) Exercise and Gene Expression: Physiological Regulation of the Human Genome through Physical Activity. Journal of Physiology 543: 399-411.

3. Ewing GW (2013) A Comparison of the Diagnostic Scope of Biomarker techniques, Genetic Screening and Virtual Scanning. Immunology, Endocrine \& Metabolic Agents in Medicinal Chemistry 13: 35-45.

4. McDonald TJ, Warren R (2014) Diagnostic confusion? Repeat HbA1c for the diagnosis of diabetes. below Diabetes Care 37: e135-136.

5. Ewing GW, Parvez SH (2010) The Multi-systemic Nature of Diabetes Mellitus: genotype or phenotype? N Am J Med Sci 2: 444-456.

6. Ewing GW, Parvez SH (2010) The Dynamic Relationship between Cognition, the Physiological Systems, and Cellular and Molecular Biochemistry: a Systems-based Perspective on the Processes of Pathology. Act Nerv Super Rediviva 52: 29-36

7. Ewing GW, Ewing EN (2008) Cognition, the Autonomic Nervous System and the Physiological Systems. J. Biogenic Amines 2: 140-163.

8. Ewing GW, Grakov IG (2013) A Further Review of the Genetic and Phenotypic Nature of Diabetes Mellitus. Case Reports in Clinical Medicine 2: 538-553.

9. Ewing GW, Parvez SH, Grakov IG (2011) Further Observations on Visual Perception: the influence of pathologies upon the absorption of light and emission of bioluminescence. The Open Systems Biology Journal 4: 1-7

10. Kurtenbach A, Schiefer U, Neu A, Zrenner E (1999) Preretinopic changes in the colour vision of juvenile diabetics. below Br J Ophthalmol 83: 43-46.

11. Ewing GW, Parvez SH (2008) Systemic Regulation of Metabolic Function. J Biogenic Amines 22: 279-294.

12. Ewing GW (2015) A Framework for a Mathematical Model of the Autonomic Nervous System and Physiological Systems using the 
Citation: Ewing G (2015) Are We so Obsessed with Technology that We Fail to Apply Basic Logic to What We See? Has the Accumulation of Data Excluded Consideration of the Quality of the Data?. Human Genet Embryol 5: 125. doi:10.4172/2161-0436.1000125

Page 2 of 2

NeuroRegulation of Blood Glucose as an Example. J Comput Sci Syst Bio 8: 59-73.

13. Ewing GW (2012) The Regulation of $\mathrm{pH}$ is a Physiological System. Increased Acidity alters Protein Conformation and Cell Morphology and is a Significant Factor in the onset of Diabetes and other common pathologies. The Open Systems Biology Journal 5: 1-12.

14. Ewing GW (2010) Mathematical modeling the neuroregulation of blood pressure using a cognitive top-down approach. below N Am J Med Sci 2: 341-352.
15. Paton JF, Raizada MK (2007) Cross-talk between the brain and other organs: is the brain to blame for hypertension? Dialogues in Cardiovascular Medicine. 12(3): 163-180.

16. Ewing GW, Parvez HS (2011) Mathematical modelling the systemic regulation of blood glucose: 'a top-down' systems biology approach. below Neuro Endocrinol Lett 32: 371-379.

17. Porges SW (2007) The polyvagal perspective. below Biol Psychol 74: 116-143. 